\title{
Incidence of Value Added Tax (Vat) in the Developing Countries: A Case in Bangladesh
}

\author{
Nahida Faridy and Tapan Sarker
}

\begin{abstract}
VAT is a broad-based tax levied at multiple stages of production (and distribution) with - crucially taxes on inputs credited against taxes on output. Bangladesh introduced VAT in 1991 replacing the previous taxes like sales tax, excise duty and business turnover taxes. In last two decades VAT has become an all encompassing domestic tax covering the domestic manufacturing, wholesale, retail and all the service sectors in the country. This paper is a first attempt to measures the incidence of Value Added Tax (VAT) in Bangladesh. The results show that the VAT incidence varies for people in different income groups. For instance, the VAT incidence for the lowest income group is 6.92 percent whereas for the highest income group it is only 4.56 percent. The higher income groups are also enjoying fewer burdens than the lower income groups. Comparing the results with and without VAT exemptions, the study finds that overall the VAT in Bangladesh is regressive. The study provides some policy recommendations that could help design a better VAT system in the developing countries with a particular case in Bangladesh.
\end{abstract}

Index Terms-Tax incidence, Value Added Tax, progressivity, empirical study, Bangladesh

\section{INTRODUCTION}

Few fiscal issues are more important in developing countries than the Value Added Tax [1]. This tax is considered to have advantages compared with other taxes, because it eliminates cascading, allows for zero rating of exports, and it is broad based and difficult to evade. VAT was first introduced on an extensive scale in France in 1954. Since then, more than 130 countries in the world had adopted a VAT of some kind. Like many developing countries, Bangladesh introduced VAT in 1991 with a view to mobilize its internal revenue collection and to bring transparency to its indirect tax system. At present, VAT is a significant source of revenue in Bangladesh. For the last 20 years more than 30 percent of revenue collected by the National Board of Revenue (NBR) in Bangladesh was from VAT and its contribution is increasing day by day. The question arises then who actually bears the burden of VAT in Bangladesh. This paper tries to answer this question by measuring the incidence of VAT in Bangladesh.

Manuscript received August1, 2010; revised September 21, 2011.

Submitted to International Journal of Trade, Economics, and Finance (IJTEF, ISSN:2010-023X). This paper was selected as the best paper in the 2011 International Conference on Financial Management and Economics ICFME 2011 held in Hong Kong, July 2-3, 2011.

Corresponding author, Tel. +61737353249, Fax: +61737353272, (Email:tapan.sarker@griffith.edu.au).

\section{INCIDENCE OF VALUE ADDED TAX IN BANGLADESH}

The study of tax incidence is, broadly defined, the studies of the effects of the tax policies on the distribution of economic welfare [2]. It is the study of who bears the burden of tax. There are various ways to measure the progressivity of taxation. An incidence analysis attempts to answer who bears the burden of a particular tax [3]. Any attempt to evaluate the "fairness" of a tax (or a change in the tax system) requires knowing whose disposable income is changed and by how much in response to the tax. Economists often refer to taxes as "regressive" or "progressive," but the confusion over the terms' meanings requires careful definitions. The definitions that most economists use rely on the average tax rate, that is, the ratio of tax liabilities to income. A tax is "regressive" if the average tax rate falls with an increase in income, "proportional" if the average tax rate is constant and "progressive" if the average tax rate rises with income. Simply put, low-income people pay a higher fraction of their income in taxes than wealthier people if the tax is regressive and a lower fraction of their income if the tax is progressive.

In Bangladesh, tax revenue accounts for about eighty percent of the total revenue of the Government. However, like in many other developing countries, very limited research has been undertaken to measure the incidence of indirect taxes and particularly for VAT in Bangladesh. Chowdhury [4] provides an estimate of the incidence analysis of indirect taxation between sectors and socioeconomic groups in Bangladesh. The study finds that the nominal tax incidence to be less than one percent for all sectors except in the industry (4.52\%) and energy (18.47\%) sectors. Effective tax incidences on the other hand, were more than one percent for all sectors. This suggests that the industrial sector shifts almost half of its nominal tax liability to other sectors. In that study, we find that the incidence of VAT on the poorest of the urban income groups is higher than that on the middle-income groups, but the incidence rises as income increases for the people of rural areas.

\section{OVERVIEW OF TAX REVENUE AND VAT IN BANGLADESH}

Sound fiscal policy is fundamental to maintain macroeconomic stability and foster economic growth of any country. Excess expenditure over revenue collection (fiscal deficit) may have an adverse effect on macroeconomic stability. This means resource mobilization, whether sourced internally or externally, is immensely important to the overall economic management of a government. In most 
developing countries, taxes are the primary sources of revenue for government. This is true in Bangladesh, where tax revenue accounts for about 80 percent of total government revenue, and the VAT alone accounts for more than 35 percent of total tax revenue [5]. Tax revenue is the main source of the Government revenue all over the world. It is the major source of mobilizing domestic resources. The government's main visions for resource mobilization are: 1 . Establish social justice and equity; 2. Provide reasonable protection to domestic industries; 3. Support growth of agriculture and rural economy and patronize small and medium enterprises; 4. Attract more investment and increase employment opportunities.

As a developing nation, Bangladesh is still heavily dependent on indirect taxes. Analysis of revenue collection activities by categories of last 19 years from the introduction of VAT shows that the bulk of revenue collection comes from the indirect taxes in spite of huge exemptions and distortions. If we take into account about individual taxes, the contribution of VAT are the highest. Income Tax occupies the second place and next positions are held by Import Duties, Supplementary Duty and Other Taxes and Duties respectively. Fig. 1 shows the share of direct and indirect taxes collected by National Board of Revenue (NBR) in Bangladesh in FY 2009-10.

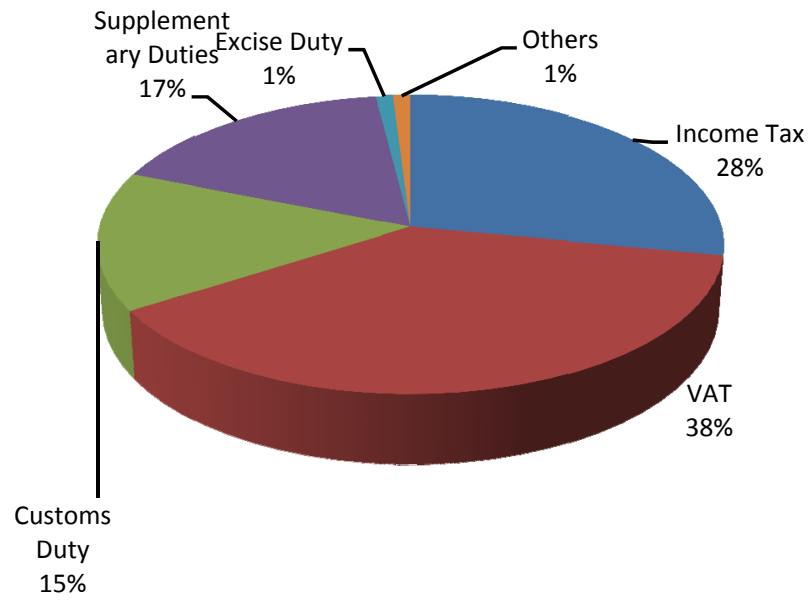

Fig. 1. Share of Direct and Indirect Taxes by NBR in Bangladesh in FY 2009-10 [6,7].

\section{HISTORY OF VAT IN BANGLADESH}

Bangladesh had a relatively complicated indirect tax system after the liberation. It failed to provide the domestic resources needed for achieving the macroeconomic goals of the government. The system relied too heavily on the taxation of imports which essentially taxed the raw materials and intermediate goods. The import based taxation performed two related functions. It was both revenue raising and protective. The structure of protection again afforded unintended protection to industries, not justified on economic grounds. It thus led to inefficiencies in production and created an overwhelming anti-export bias. Since, around sixty percent of the total tax revenue is collected from the import based taxation, revenue collection in Bangladesh effectively became a hostage to the balance of payments situation. The system of excise taxation used for collecting revenue from domestic production and services was also badly flawed. The base was very narrow; there were too many rates and exemptions. In the absence of a credit mechanism substantial cascading was prevalent. There was also a lack of harmony in regard to the tax treatment of the imports and the domestically produced goods. The resultant effects of all these were that the taxGDP ratio in Bangladesh was one of the lowest in the world and the system of taxation was inefficient, distortionary and inelastic. So to overcome all these obstacles and to activate the overall economy by mobilizing more in internal resources, to bring a consistency in the tax-GDP ratio and to bring transparency in the entire taxation system in April 1979, The Taxation Enquiry Commission (TEC) officially took up the issue of introducing VAT in Bangladesh as an alternative to sales tax. The objective behind introducing VAT in Bangladesh were to (a) bring transparency in the taxation system; (b) prohibit cascading taxation at different stages of production; (c) consolidate the tax administration; (d) activate the overall economy by mobilizing more in internal resources; and (e) bring a consistency in the taxGDP ratio.

From the very beginning, VAT in Bangladesh has been quite instrumental in gradually mobilizing more domestic resources in line with the growth trend of economic development. In spite of many exemptions, VAT is the leading revenue in NBR. Its contribution is the highest in the total revenue of NBR. But the revenue authority should concentrate on the gap between potential VAT revenue and actual VAT revenue and the underground economy of Bangladesh. Because of the guidelines of the WTO and trade liberalization, the government reduced customs duties drastically. So government didn't have any other better alternatives without depending on VAT revenue. One another important thing behind the introduction of VAT was reducing dependency on foreign loans. Thus, replacing traditional excise duties and sales tax government introduced VAT and it has been quite instrumental in gradually mobilizing more domestic resources in line with the growth trend of economic developmental. In spite of many exemptions, VAT is the leading revenue in NBR. Its contribution is the highest in the total revenue of NBR. In the first year of introduction VAT, at FY 1991-92, total VAT was collected 17.352 billion taka. It was 23 percent of the total collected revenue of NBR at that period. In FY 2007-08, the total VAT was 170.13 billion taka which was 4.6 percent of GDP. In FY 2009-10, total VAT collection reaches to 241.40 billion taka, 38.84 percent of total revenue collected by NBR. VAT collection trend and scenario from FY 2001-02 to FY 2009-10 is shown below in Table 1. 
TABLE 1: TAX REVENUE RECIEPT In MAJOR TAXES TyPe (NBR) (In Billion Tk.)

\begin{tabular}{|l|r|r|r|r|r|r|r|r|r|}
\hline Year & $2001-02$ & $2002-03$ & $2003-04$ & $2004-05$ & $2005-06$ & $2006-07$ & $2007-008$ & $2008-09$ & $2009-10$ \\
\hline $\begin{array}{l}\text { Income } \\
\text { tax }\end{array}$ & 41.01 & 47.91 & 52.7 & 58.5 & 69.6 & 89.24 & 110.05 & 135.38 & 171.54 \\
\hline VAT & 69.61 & 80.73 & 85.75 & 106.05 & 123.98 & 136.83 & 170.13 & 201.16 & 241.40 \\
\hline CD & 53.52 & 58.81 & 73 & 80 & 82.35 & 82.79 & 93 & 95.7 & 94.10 \\
\hline $\begin{array}{l}\text { Excise } \\
\text { duty }\end{array}$ & 3.05 & 3.14 & 1.7 & 1.5 & 1.63 & 1.85 & 2.13 & 2.37 & 3.50 \\
\hline SD & 38.51 & 43.91 & 54.3 & 56 & 63.94 & 60.95 & 79.7 & 91.21 & 107.06 \\
\hline Others & 1.72 & 3.25 & 3.05 & 2.95 & 3.06 & 3.13 & 4.69 & 4.18 & 3.97 \\
\hline Total & 207.42 & 237.50 & 270.50 & 305 & 344.56 & 374.79 & 459.70 & 530 & 621.57 \\
\hline
\end{tabular}

Source: Bangladesh Economic Review [8]. [Notes: SD = Supplementary Duty, CD = Customs Duty]

The VAT in Bangladesh has a broader coverage compared to the bases of taxes it has replaced. However, Bangladesh is a developing nation, which means that its VAT has a number of exemptions for equity reasons, making it less efficient and more distortionary than it would otherwise be. Exemptions from the VAT include such items as live animals, poultry, fish, meat, liquid milk, vegetables, fruits, herbs and spices, animal hides, fuel wood, raw jute etc. In addition, services for livelihood, services for social welfare, services related to charity, government education etc. is also exempted from VAT. People in Bangladesh, especially the low income group people spend their 60 percent of income for consumption of food items and most of the food items are exempted from VAT for equity reasons. A sense of the scope of the exemptions can be gained from Table 2. It should be noted that the underground economy in Bangladesh, estimated to amount to $37 \%$ of the country's GDP during the beginning of the 2000s, has also contributed to the under-collection of VAT [9].

TABle 2: Potential VAT And Actual VAT Collection By NBR (In Crore Tk.)

\begin{tabular}{|l|l|l|l|l|l|l|l|}
\hline Year & $\begin{array}{l}\text { Potential } \\
\text { VAT }\end{array}$ & $\begin{array}{l}\text { Actual } \\
\text { VAT }\end{array}$ & $\begin{array}{l}\text { Ratio of } \\
\text { collection }\end{array}$ & Year & $\begin{array}{l}\text { Potential } \\
\text { VAT }\end{array}$ & Actual VAT & $\begin{array}{l}\text { Ratio of } \\
\text { Collection }\end{array}$ \\
\hline $1997-98$ & 16,312 & 4,579 & 28.07 & $2003-04$ & 23,317 & 8,575 & 36.77 \\
\hline $1998-99$ & 17,170 & 4,831 & 28.13 & $2004-05$ & 25,028 & 10,615 & 42.41 \\
\hline $1999-00$ & 18,199 & 5,170 & 28.40 & $2005-06$ & 27,017 & 12,398 & 58.99 \\
\hline $2000-01$ & 19,375 & 6,372 & 32.88 & $2006-07$ & 29,079 & 13,683 & 47.05 \\
\hline $2001-02$ & 20,574 & 6,981 & 33.93 & $2007-08$ & 31,065 & 17,013 & 54.76 \\
\hline $2002-03$ & 21,882 & 8,073 & 36.89 & $2008-09$ & 32,985 & 20,116 & 60.98 \\
\hline
\end{tabular}

Source: $[5,10]$. Note: 1 Crore $=10$ million

As shown in Table 2, the ratio of potential to actual VAT is increasing year by year. As the Government is expanding the VAT net and exemption list is gradually decreasing, the actual VAT collection situation is improving. Given the high level of poverty in Bangladesh and the number of exemptions from the VAT, it becomes important to measure the progressivity (or otherwise) of the VAT in Bangladesh, and whether any improvements to the current situation can be made.

\section{DATA AND MethodS}

This study primarily used the Household Income Expenditure Survey (HIES) 2005 data to measure the incidence of VAT in Bangladesh. Additional data available from other government sources, including the National Board of Revenue (NBR) and Bangladesh Bank were also used. To measure the incidence of VAT, we first calculate the Effective VAT Rate on the following way:

Effective VAT Rate $=[($ Actual VAT paid $/$ Per capita consumption) $\mathrm{x}$ 100]

The Effective VAT Rate among different income groups can show us whether the tax system is progressive or regressive. The Relative Tax Burden Index is also important to determine the progressiveness of a tax, which is defined as the ratio (expressed in percentage terms) of its share of total taxes to its share of total income. The relative tax burden concept is also important to determine the progressiveness of a tax. The relative tax burden of each quintile is defined as the ratio (expressed in percentage terms) of its share of total taxes to its share of total income. For instance, a quintile paying 10 percent of aggregate tax and receiving 15 percent of total income would have a relative tax burden of 66.6 percent. In this study to determine the progressiveness of VAT on individual expenditure items, the relative tax burden index for various income groups has been computed. If the value of the index for a income group is greater (less) than 100, then that group is paying a greater (smaller) proportion of their income in VAT. The VAT tends to be progressive (regressive) if the value of this index increases (decreases) as we move up from the lower to higher income groups. In this study to determine the progressiveness of VAT on individual expenditure items, we calculate the relative tax burden index for various income groups. The Relative tax burden index and effective VAT rates can give an overall picture about VAT, whether it is progressive or regressive. However, to measure how progressive the VAT is or how regressive it is, Suits Index of Progressivity and Kakwani Index was used in this study. Because of some basic differences, the two measures may lead to quite different results about the degree of progressivity. Suits' Index of Progressivity is used to calculate the VAT incidence at urban and rural levels based on the following formula:

$$
\text { Suits Index of Progressivity or } S_{x}=1-\left(\frac{L_{x}}{K}\right)
$$

where $\mathrm{S}_{\mathrm{x}}$ is the progressivity index, $K$ is the area of the triangle and $L x$ is the covered area below the Lorenz curve.

Finally, the Kakwani Index compares the Lorenz curve of pre-tax income and the concentration curves of taxes. The 
progressivity or regressivity of the overall indirect system is calculated by:

$$
P=\left(\sum_{i=1}^{n} \mu_{i} \alpha_{i} P_{i}\right) /\left(\sum_{i=1}^{n} \mu_{i} \alpha_{i}\right)
$$

Where a positive value of $\mathrm{Pi}$ means the tax is progressive and the negative value of Pi means the tax is regressive [11]. It was mentioned earlier that more than eighty percent of Bangladesh's VAT revenue is sourced from 9 to 10 items. So, it is clear, if we can measure the progressivity of those main VAT generating items we can get some effective results. For example, more than 25 percent of VAT revenue is earning from tobacco and tobacco products. A major share of VAT revenue comes from medicine, gas, telephone, construction companies and from petroleum products. So in this study, it has been taken into account of that items which have a major contribution to VAT in Bangladesh. All the taxable commodities are segregated from the total consumption of each household based on the list of exempt goods and services stated in the First Schedule of The VAT Act 1991. Although in reality sellers and consumers may share the burden partially, this study assumes the VAT is fully shifted from the seller to the final consumer.

\section{RESULTS}

Table 3 presents the Effective VAT Rates and shows how the burden of the $15 \%$ VAT varies with the changes of percapita household income. The average effective tax rate is 6.01 percent and the rate varies as the income ranges with the minimum of 4.56 percent to maximum 6.92 percent of their income.

TABLE 3: EFFECTIVE VAT RATES IN BANGLADESH IN FY 2005-06

\begin{tabular}{|c|r|r|r|r|}
\hline Income Group & $\begin{array}{r}\text { Income Range } \\
\text { (In Tk.) }\end{array}$ & $\begin{array}{r}\text { Per Capita } \\
\text { Consumption }\end{array}$ & $\begin{array}{r}\text { VAT Paid } \\
\text { (In Tk.) }\end{array}$ & $\begin{array}{r}\text { Effective VAT Rate } \\
(\%)\end{array}$ \\
\hline 1 & $<3,999$ & $2,996.29$ & 207.34 & 6.92 \\
\hline 2 & $4,000-4,999$ & $4,757.51$ & 319.70 & 6.72 \\
\hline 3 & $5,000-5,999$ & $5,371.19$ & 338.92 & 6.31 \\
\hline 4 & $6,000-6,999$ & $6,055.52$ & 352.43 & 5.82 \\
\hline 5 & $7,000-7,999$ & $6,681.90$ & 432.31 & 6.47 \\
\hline 6 & $8,000-8,999$ & $7,367.67$ & 450.90 & 6.12 \\
\hline 7 & $9,000-9,999$ & $7,345.70$ & 453.22 & 6.17 \\
\hline 8 & $10,000-12,499$ & $8,940.37$ & 540.89 & 6.05 \\
\hline 9 & $12,500-14,999$ & $10,251.07$ & 608.91 & \\
\hline 10 & $15,000-17,499$ & $11,971.06$ & 713.47 & \\
\hline 11 & $17,500-19,999$ & $12,720.51$ & 638.56 & 5.94 \\
\hline 12 & $20,000 \&$ above & $19,119.01$ & 871.82 & \\
\hline & Average & 8631.00 & 494.03 & 5.02 \\
\hline & & & & 4.56 \\
\hline
\end{tabular}

Source: Household Income Expenditure Survey, 2005 [12]. Note: 1.00 USD = 73 Tk

The VAT burden in the lowest income range is 6.92 percent, which is extremely high given the fact that the VAT burden of the highest income group is only 4.56 percent. The $4^{\text {th }}$ income group people bear 5.82 percent of VAT burden which is lower than $3^{\text {rd }}$ income group people. The average effective VAT rate is 6.01 percent, which is higher than that of highest fourth income groups' people.
The higher income groups are enjoying fewer burdens than the lower income groups.

Table 4 presents the numerical results giving the income share, the tax share and the relative tax burden of VAT for each income group. The actual relative tax burden of VAT and the VAT share without exemptions are also shown.

TABLE 4: RELATIVE BURDEN INDEX OF VAT IN BANGLADESH

\begin{tabular}{|c|c|c|c|c|c|c|}
\hline Income group & $\begin{array}{r}\text { Monthly Household } \\
\text { Per-Capita Income } \\
\text { (in Tk.) }\end{array}$ & $\begin{array}{r}\text { Income } \\
\text { Share } \\
\text { (A) }\end{array}$ & $\begin{array}{r}\text { Actual VAT } \\
\text { Share (B) }\end{array}$ & $\begin{array}{r}\text { Relative Tax } \\
\text { Burden } \\
(\text { B/A)x100 }\end{array}$ & $\begin{array}{r}\text { VAT Share } \\
\text { Without } \\
\text { Exemptions } \\
(\mathrm{C}) \\
\end{array}$ & $\begin{array}{r}\text { Relative Tax Burden } \\
(\mathrm{C} / \mathrm{A}) \times 100\end{array}$ \\
\hline 1 & $<200$ & 0.49 & 1.98 & 404 & 3.18 & 648 \\
\hline 2 & $200-249$ & 0.89 & 2.09 & 234 & 3.03 & 340 \\
\hline 3 & $250-299$ & 1.08 & 2.10 & 194 & 3.36 & 311 \\
\hline 4 & $300-349$ & 1.27 & 2.13 & 168 & 3.07 & 242 \\
\hline 5 & $350-399$ & 1.47 & 2.62 & 178 & 3.38 & 230 \\
\hline 6 & $400-449$ & 1.66 & 2.49 & 150 & 3.29 & 198 \\
\hline 7 & $450-499$ & 1.86 & 2.55 & 137 & 3.30 & 177 \\
\hline 8 & $500-599$ & 2.15 & 2.94 & 136 & 3.46 & 161 \\
\hline 9 & $600-799$ & 2.68 & 3.00 & 115 & 3.60 & 138 \\
\hline 10 & $700-799$ & 2.92 & 3.58 & 123 & 3.88 & 133 \\
\hline 11 & $800-899$ & 3.31 & 3.96 & 120 & 4.11 & 124 \\
\hline 12 & $900-999$ & 3.70 & 4.03 & 108 & 4.37 & 118 \\
\hline 13 & $1,000-1,249$ & 4.37 & 4.91 & 112 & 4.97 & 114 \\
\hline 14 & $1,250-1,499$ & 5.32 & 5.67 & 107 & 5.52 & 104 \\
\hline 15 & $1,500-1,999$ & 6.74 & 7.30 & 108 & 6.35 & 94 \\
\hline 16 & $2,000-2,499$ & 8.68 & 8.63 & 99 & 7.58 & 87 \\
\hline 17 & $2,500-2,999$ & 10.58 & 10.48 & 99 & 9.15 & 86 \\
\hline 18 & $3,000-3,499$ & 12.44 & 11.56 & 93 & 9.20 & 74 \\
\hline 19 & $3,500 \&$ above & 28.39 & 17.98 & 63 & 15.20 & 54 \\
\hline Total & & 100 & 100 & & 100 & \\
\hline
\end{tabular}


Actual relative tax burden for the lowest income group was 404, but if there is no exemption list it reaches to 648 . Again the actual VAT share for the poorest group was 1.98 , but if there is no exemption list, the VAT share for poor people will be 3.18. This means, exempted goods and services are helping poorer group to take less burden of VAT. The results shows that, without exemptions the relative tax burden varies for lower income group but for higher income people it has a little impact and for the higher six income groups the value of relative tax burden without exemptions is lower than the actual VAT burden. The tax tends to be progressive (regressive) if the value of the relative tax burden index increases (decreases) as we move up to the lower to higher income groups [13]. Table 5 summarizes the progressivity of VAT based on Suit's Index at the national level as well as for urban and rural levels including with and without VAT exemptions. The index shows that the degree of progressivity of tax burden distributions for national level, rural and urban people.

TABLE 5: PROGRESSIVITY OF VAT OF BANGLADESH BASED ON SUITS' INDEX

\begin{tabular}{|c|r|r|r|r|r|r|}
\hline $\begin{array}{l}\text { Particu } \\
\text { lars }\end{array}$ & \multicolumn{3}{|c|}{ With Exemptions } & \multicolumn{3}{c|}{ Without Exemptions } \\
\hline & Natio & Urba & Rural & Natio & Urba & Rural \\
& $n a l$ & $n$ & & $n a l$ & $n$ & \\
\hline Lx & 5851. & 5978. & 5845. & 6352. & 6420. & 6189. \\
& 281 & 997 & 342 & 455 & 530 & 495 \\
\hline$K$ & 5000 & 5000 & 5000 & 5000 & 5000 & 5000 \\
\hline Sx & - & - & - & - & - & - \\
& 0.170 & 0.195 & 0.169 & 0.271 & 0.284 & 0.238 \\
\hline
\end{tabular}

Source: [5]

This table gives us some interesting results. VAT is regressive in all cases but without exemptions it is more regressive. This is natural as the regressiveness of the VAT is alleviated by exemptions of products which rank high in the budget of the lower income people. On the other hand, low income households spend more on consumption of food items and rich households spend less on consumption of food and more on non-food items (Engle's Law). But VAT is less regressive $(S x$ is -0.169$)$ to the rural people with exemptions. In HIES 2005, it is found that 58.54 percent consumption expenditure was accounted for by food and beverage in the rural area, whereas, the same was 45.17 percent in the urban area. It is mentioned earlier that most of the food items are exempted. So for the group who consumes more on food and other non-taxable items, VAT will be less regressive. The rural households tend to purchase a larger portion of goods and services from the informal retail sector where the goods are either not taxed at all or are more lightly taxed. So, VAT is less regressive in rural areas. Without exemptions the value of $S x$ for urban ($0.284)$ is higher than rural (- 0.238). Informal sector and less emphasis to the rural areas and districts other than big cities by the tax administration are other main reasons to make VAT less regressive in rural areas. So the conclusion can be made based on the findings that, VAT is regressive in Bangladesh as a whole and urban households are bearing more burdens than rural households.

The Kakwani Index gives a similar picture. Employing a figure similar to a Lorenz curve, we plot the accumulated percent of VAT burden vertically against the accumulated percent of income on the horizontal axis. Fig 2 represents the progressivity of VAT based on total income of each income group. If the VAT is proportional the curve of would follow the diagonal line of per-capita income.

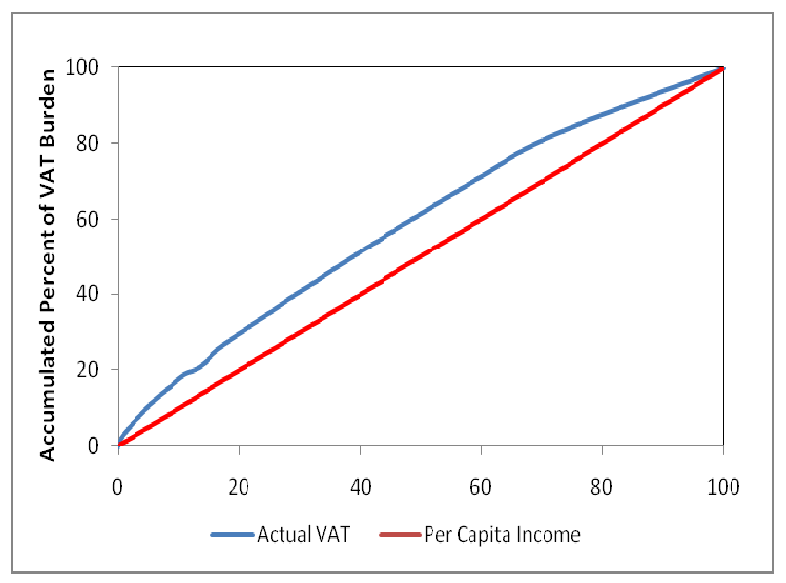

Fig.2. Actual VAT Burden of Bangladesh at FY 2005-06. Source: [5].

Since the tax burden borne by the lowest income group is higher than the share of the total income the Actual VAT curve stands upper the diagonal. This curve shows that VAT burden in income groups is regressive, supporting our earlier conclusions from Suits' Index above.

\section{CONCLUSION}

The present empirical study showed that the VAT burden in the lowest income range is 6.92 percent, which is extremely high given the fact that the VAT burden of the highest income group is only 4.56 percent. The average effective VAT rate is 6.01 percent, which is higher than that of the highest fourth income groups' people. The higher income groups are enjoying fewer burdens than the lower income groups. One of the "Canons of Taxation" developed by Adam Smith said that a tax should be linked to "Ability to Pay". VAT does not lie in with this because the amount of VAT of a particular commodity will be the same for everyone, however much they earn. On the other hand, a good tax system should be fair in its treatment of different individuals, should be able to ascertain tax burden so that burden can be politically tailored to what society considers desirable and should keep the exemptions and deductions at a minimum level [20].

However, the reality is totally different in a developing country like Bangladesh where income redistribution is strictly unequal, poverty is hard to reduce, land distribution is quite eccentric and where political norms and values are yet to establish. Like all other countries, VAT is used as a tool of collecting revenue in Bangladesh, rather than to correct inequalities- although a big exemption list exists. Although deemed to be necessary given the poverty in Bangladesh, extensive exemptions are sub-optimal because they create significant distortions. They can also create a competitive advantage for imports over domesticallyproduced exempt item. Besides this, in FY 2005-06, tax expenditures for VAT at domestic stage was estimated to be about 1.6 percent of GDP and more than 60 percent of total 
revenue loss. Some have suggested that, instead of giving so many exemptions, a reduced rate of VAT could be a better choice. But the key point here is that even if the poor group spends a larger share of their income for some particular items (food, for example), the rich will typically spend a larger absolute amount; so a reduction in the tax rate for basic items or exemptions on those items actually means more money to the rich than it does to the poor. One can also think that, more revenues are available to the government for limited exemptions and less tax expenditure, then equity aspect could be better taken care of by increasing the supply of Government services to the poor, such as better housing, better education, improved medical care and modern transportation system.

\section{REFERENCES}

[1] M. Bird, "The VAT in Developing and Transitional Countries," New York: Cambridge University Press, 2007.

[2] L. Kotlikoff and L. Summers, "Tax Incidence" in Handbook of Public Economics, A. Auerbach and M. Feldstein (eds), Amsterdam: North-Holland, 1987.

[3] T. Sarker, "Who Bears the Burden of Taxes in Developing Countries? A Case of Income Taxation in Bangladesh", Pakistan Economic and Social Review, 44(2): 181-207, 2006.

[4] O. Chowdhury, "Incidence of Indirect Taxation in Bangladesh: 1984/85", Research Monograph No. 16, Bangladesh Institute of Development Studies (BIDS), Dhaka, Bangladesh, 1994.

[5] N. Faridy, "Progressivity of Value Added Tax (VAT) in Bangladesh", M.S Thesis, Keio University, Japan, 2011.

[6] Bangladesh Economic Review, "Bangladesh Economic Review 2009", Ministry of Finance, Government of the People's Republic of Bangladesh, 2009.

[7] National Board of Revenue, “Annual Report 2008-09”, Bangladesh Government Press, National Board of Revenue, Ministry of Finance, Government of the People's Republic of Bangladesh, 2009.

[8] Bangladesh Economic Review, "Bangladesh Economic Review 2009”, Ministry of Finance, Government of the People's Republic of Bangladesh, 2009.
[9] N. Park, Underground economy: causes and size, presentation by Korea Institute of Public Finance, Seoul, 2005.

[10] Bangladesh Bureau of Statistics, "Statistical Pocket Book Bangladesh", Government of Bangladesh, 2007.

[11] N. Kakwani, Analyzing Distribution Policies: A study using Australian Data, Cambridge University Press, Cambridge, UK, 1986.

[12] Household Income \& Expenditure Survey (2005) Bangladesh Bureau of Statistics, Ministry of Planning, Government of the People's Republic of Bangladesh.

[13] A. Atkinson and J. Stiglitz, Lectures on Public Economics McGraw Hill, New York, 1980.

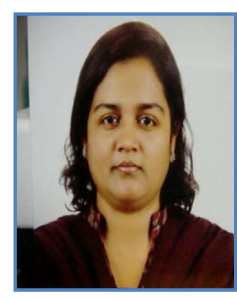

Nahida Faridy is a Deputy Commission of Customs (Import) with Chittagong Customs House, National Board of Revenue, Bangladesh. Prior to joining in her current role, she worked as a Second Secretary (VAT) with the VAT wing of National Board of Revenue, Bangladesh. Her areas of expertise include Value Added Tax (VAT) design and administration, modernization of Customs and VAT administration, and capacity building in tax policy and administration in developing countries. Nahida obtained first class Honors and Master's in Economics from Dhaka University, Bangladesh, and a Master's in Tax Policy in Management from Keio University, Japan. Nahida was a recipient of prestigious World Bank Scholarship (2009-2011) at Keio University, Japan. Her recent research on VAT reform in developing countries has been awarded as a best paper in the 2011 International Conference on Financial Management and Economics - ICFME 2011 held in Hong Kong, July 2-3, 2011.

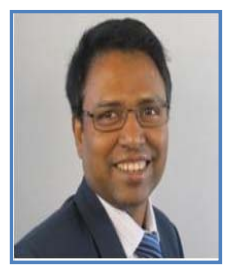

Tapan Sarker (PhD, Australian National University) is a Lecturer and Researcher with Griffith Business School, Griffith University, Australia. He also works as a Tax Policy Consultant with the World Bank, Asian Development Bank and IMF. Dr Sarker is currently listed as an expert in Tax Policy with the Fiscal Affairs Department of International Monetary Fund. His research has been published in pretigious tax journals, including Bulletin for International Taxation, Asia Pacific Tax Bulletin etc. Dr Sarker was a keynote speaker at the 2011 International Conference on Financial Management and Economics - ICFME 2011 held in Hong Kong, July 2-3, 2011. 